\title{
DESPRE UN MOTIV DECORATIV MAI PUŢIN CUNOSCUT DIN SUD-ESTUL EUROPEI
}

Silviu Oţa

\section{ON A LESS KNOWN DECORATIVE MOTIF OF SOUTH-EASTERN EUROPE}

Abstract: In time, especially during the last century, in SE Europe have been discovered a few earrings with an ornament less used in the Balkan area. We are taking about those items known under the generic title of Cumanian-type earrings or earrings with Cumanian-type elements. One can notice, however, that beside them there are also other items decorated similarly, yet whose geometric figure used may be different (pyramids, paraboloids, cones and tetrahedrons). In order not to produce confusions, I have chosen to analyze all the abovementioned models.

This study comprises a catalog of the SE European discoveries, the analysis of the context the items have come from, their relative and absolute dating and the repartition of the forms of ornamental work for each type of items.

Following this analysis, we can say that four types of ornamental work have emerged, made of silver sheet, golden sheet, bronze sheet or silvered bronze.

Depending on the models of earrings on which they appear, several types and subtypes of earrings can be distinguished.

In chronological order, the first decorative group is made up of the earrings decorated with paraboloids. From a gcographic viewpoint, these earrings comprise two areas of circulation.

The first one is in the Dalmatian area. Their chronology is circumscribed by the $9^{\text {th }}-10^{\text {th }}\left(11^{\text {th }}\right)$ centuries. From a typological viewpoint, we can discern two large groups. The first is made up of the items discovered in the cemeteries of Bribir, Brenkovac and Biskupija. They are characterized by the setting decorated with three lines of paraboloids. Among them, three variants can be distinguished: 1) the items of Bribir, 2) the items of Brenkovac, 3) the item of Biskupija.

The second group is represented by a item discovered at Biskupija.

The second region of circulation is in the East Balkan area. The items found here are of a later date and belong to the $14^{\text {th }}$ century. In this case the items are formally almost identical, yet the material they are made of and the number of their pendants differ. According to this criterion, we can discern three variants: 1) the item of Coconi, 2) the itcms of Dobrogled, 3) the earring of Isaccea-Burg, 4) a pair of earrings of Divdiadovo and 5) another pair with two spherical settings coming from the same locality. The fact that they are made of different materials (bronze. silvered bronze and gold) suggests that they come from different workshops. The limitation of their circulation to the NE Balkans suggests that it is here that their manufacturing and use was in fashion and we can only talk about a product used regionally.

$\wedge$ second decorative group is made up of cones. Here, as well, we can make a distinction between several types, groups and sub-groups of earrings on which this decorative work appears.

The simplest type is made up of the earring discovered at Enisala, decorated with just one setting. From the viewpoint of the geographic repartition, it is circumscribed by the $\mathrm{N}$ and $\mathrm{W}$ Pontic area, controlled by the Turkic tribes. Its chronology suggests a dating to the $12^{\text {th }}-13^{\text {th }}$ centuries.

The second type comprises the earrings decorated with three settings (Braničevo-Rudine, Kalna, Cernăuıti, Prilep, Cuproare-Sfogea, Păcuiul lui Soare, Jiana Mare). According to the way in which the ring of the earring was executed, we can distinguish two types, namely simple and made up of Turkic-style wires. Within each of these two types, we can discern several groups, according to the characteristics of execution of the rings and settings.

The first group comprises the items found at Braničevo and Kalna (simple rings of the earrings, identical decorative work on all the three pendants, different dimensions of the settings). The similitude of manufacturing and the area of circulation suggest that they come from a common workshop from the Middle Danube which functioned some time towards the end of the $13^{\text {th }}$ century and eventually at the beginning of the future century.

The second group comprises the items that have the lateral pendants decorated differently from the central one (Cernăuli, Voineşti, Prilep, Cuptoare-Sfogea, Păcuiul lui Soare and Jiana Mare).

The first sub-group is made up of the items of Cernăuti (simple ring of the earring). 
The second is made up of the items whose ring is made of tore-type wire (Voineşti, Voineşti. Prilep, Cuptoare-Sfogea, Păcuiul lui Soare). Depending on the model of the decorative work found on the central pendant and according to the way the lateral pendants were executed, the following variants can be distinguished:

a.Prilep, Cuptoare (perforated lateral settings).

b.Voincşti (lateral settings decorated with pseudo-granules).

c.Păcuiul lui Soare (lateral settings made of discs).

To these can be added one more item, namely the one discovered in the treasure of Jiana Mare. In this case. we do not know for sure whether the ring of the earring was simple or made in a torc-style manner. The analogies to similarly decorated items suggest that most of the earrings decorated with ellipsoid-shaped settings had their ring made of two wires put together in a torc-style manner. In this sense, I would quote the items of Olteni. Jiana Mare and Jidosifa.

Their chronology indicates the use of these earrings beginning with the last quarter of the $13^{\text {th }}$ century until the first 20 years of the $15^{\text {th }}$ century.

The third decorative group comprises items decorated with pyramids made of metallic sheet. In this case, we can single out two groups. The first of them is constituted of earrings with a simple ring (Skravena, DrobetaTurnu Severin, Stara Zagora and Sumen). If the items of the first two localities are extremely similar, those of Stara Zagora and Sumen suggest different manufacturing workshops. The chronology of the first ones is quite clear, being situated in the second quarter of the $13^{\text {th }}$ century.

On the basis of the relative chronology can be dated as well the items of Stara Zagora and Sumen, namely very probably the boundary between the $13^{\text {ll }}$ and the $14^{\text {th }}$ century.

The second group is made up of the earrings discovered at Dragijevo. Considering their decorative features, they can be divided in their turn into two sub-groups. The first is made up of the pair of earrings with perforated lateral pendants. The second is represented by the third earring in the treasure. Their dating has been made especially based on an absolute chronology, towards the end of the $13^{\text {th }}$ century and the beginning of the $14^{\text {th }}$ century. To these items can be added a partially destroyed item coming from an unknown locality in Bulgaria.

$\Lambda$ lourth decorative group is made up of the item of Nikopolis. It can be dated to the $14^{\text {th }}$ century based on its manulacturing and decorative features.

Following this analysis, we can say that we are in front of several decorative models in relief applied on the pendant of some earrings, without being able to attribute them from an ethnic viewpoint. The fact that they appear as paraboloid, pyramid, cone or tetrahedron does not represent anything else but variations and local preferences of the population or of the artisans who manufactured these items. Another argument would be that they appear on several types of earrings, not just on a particular one.

At the same time, the attempt of attributing the biconical pendant to the influences of the Cumanian population is wrong. They can be found among the jewelry found in this region long before the Cumanians' coming to different SE European regions. Not even the style of the decorative work can be connected to a peculiar population. We would rather say that it was in fashion in certain areas and during certain periods of time. The use of the term C'umanian-type earrings is rather due to some archeologists' desire to distinguish between a certain model of earrings and others (sometimes those with a biconical pendant). This tendency is caused as well by the fact that in this way they want to prove or at other times to remark the influence of the Cumanian goldsmiths, making a difference between them and the others that were active among the other populations of SE Europe. It is for the same purpose that the argument of the supplementary decorative work applied to the pendants of certain earrings was used. This desire has led to confusions between different types of earrings such as for instance the Tokaj-type earrings and the Cumanian-type carrings.

Keywords: gold, silver, bronze. earring, treasure, tomb, cone

Cuvinte chcie: aur, argint, bronz, cercel, tezaur, mormânt, con

De-a lungul timpului, mai ales în ultimul secol, au fost descoperiţi în sud-estul Europei câţiva cercei cu un omament mai puţin utilizat în arealul balcanic. Este vorba de acele exemplare cunoscute sub denumirea generică de cercei de tip cuman sau cu elemente de tip cuman'. Se poate observa însă că în afara lor mai există şi

\footnotetext{
1 Termenul de cercei de tip cuman apare în literatura de specialitate din România pentru a delinii exemplarelo care pe pandantiv au montate ornamente în lormă de conuri. La accasta se adaugă laplul cã toate lipurile de decor (conuri. piramide, paraboloide și tetraedre) pot
} 
piese decorate asemănător, dar forma geometrică spạ̧ială utilizată poate fi diferită (piramide, paraboloide şi tetraedre). Pentru a nu crea confuzii, analiza care urmează a luat în considerare toate modelele ornamentale amintite.

Studiul de faţă, nu își propune să rcalizeze o tipologie a acestor piese, ci să aduc în discuţie decorul care individualizează exemplarele menţionate.

Intenţia este aceea de a selecta tipurile de cercei la care a fost sesizat omamentul în formă de con şi variantele sale, executate din foiţă de aur, argint, bronz sau bronz argintat. De asemenea, stabilirea formelor geometrice utilizate pentru confecţionarea decorului aplicat pe pandantivul sau montura cerceilor. Plecând de la aceste observaţii se pot indica relativ zonele de producţie şi aria de difuzare a pieselor.

$\mathrm{O}$ altă precizare trebuie realizată, anume că în decursul timpului se poate constata că motivul decorativ studiat şi variantele sale, pe cercei de diverse tipuri, a început să fie executat şi din granule de argint. Pentru piesele din actualul spaţiu românesc sunt de amintit cazurile câtorva cercei descoperiţi la Enisala², Drobeta-Turnu-Severin ${ }^{3}$, Zăvoaia ${ }^{4}$, Jiana Mare $^{5}$, Măicăneşti-Străuleştí şi un exemplar

apărea pe cercéi dilerili tipologic. De aceea este discutabil dacă piescle amintitc se mai justifică a fi considerate ,.de lip cuman” sau nu, şi dacá nu mai degrabă conţin elemente decorative de tip cuman. De asemenea trebuie vãzul care tipuri de cercei apar în complexe funerare care ar putea fi atribuite populaţiilor turkicc. precum şi frecvenţa lor în astfel de complexe. La accasta se adaugã faptul că în literalura de specialitate şi alţi cercei. anume cei cu pandantiv biconic. au fost consideraţi uneori ca fiind tot de tip cuman. Analizat nu într-o ordinc anume. putem spune cã o parte a celor care au descoperit astfel de piese şi a celor care le-au studiat. se constală douã tendinfe. Prima este aceea de a descrie pur și simplu piesa. lărā altã apreciere (Constantinescu 1972. 100: Diaconu. Baraschi 1977. 125: Dumitriu 2001. 39-40. 1/2). O a doua grupă este constituită din arheologi care includ in acest tip de cercei piesele care au pe verigà o montură centralā decoratã printre altele cu conuri şi altele douã (n. n. monturi) mai mici, dispuse în lateralul celei dintâi (D. Teicu, S. Ota, D. Gh. Teodor). Aproximativ aceleaşi tendinţe se observă şi în literatura de specialitate din spaţiul balcanic.

${ }^{2}$ Dumitriu 2001. 107, Taf. 16/5-6.

${ }^{3}$ Dumitriu 2001, 123, Taf. 23/4. În text, la pagina indicatā. apare cu numārul 5, iar în ilusıraţie cu numărul 4.

${ }^{4}$ Dumitriu 2001. 139. Tal. 51/3-4.

5 Dumitriu 2001. 127, Tal. 39/1-2, 2 a, 4, 5. 5a.

6 Dumitriu 2001. 129, Tal. 93/11. cu loc de descoperire necunoscut ${ }^{7}$ (Tara Românească). Alteori au fost executat din sâme şi granule, ca în cazul unor piese din spaţiul croat, de la Biskupija-Crkvina ${ }^{8}$, Biljane Donje-Begovača (M. 228) ${ }^{9}$, Đevrske ${ }^{10}$. Pe acestea, însă nu le voi avea în vedere.

\section{Repertoriul descoperirilor}

\section{România}

\section{Necropolă}

I.1. Cuptoare (com. Cornea, jud. CaraşSeverin)

Punct: Sfogea; ansamblu: necropolă de înhumaţie.

Mormântul 189, plan; individual; înhumaţie; inventar: doi cercei de tâmplă, din argint, de tip Tokaj sau, după alte tipologii, de tip cuman (Pl. 2/78). Veriga este dintr-o sârmă de argint pusã în două şi torsionată. Pe ea au fost montate două sfere ajurate, de aceeaşi dimensiune, de o parte şi de alta a unei sfere centrale, mai mari, decorată cu conuri din foiţă de argint, în vârful cărora sunt piramide de câte patru granule. Monturile au fost fixate pe verigă cu sârmă de argint.

Bibliografie: Teicu 1993, 245, 268, fig. 11/5-6; Teicu 1998, 37, 163, fig. 45/5-6; Oța 2008, 97, 231-232, Pl. 55/8-9; Oţa 2009a, 80, 84, 96, fig. 3/5; Teicu 2009, 188-189, 261, fig. 21; Oţa 2010, 117-118, 121, PI. 3/1-2.

\section{I.2. Enisala (com. Sarichioi, jud. Tulcea)} înhumaţie.

Punct: Burg; ansamblu: necropolă de

Cercel din bronz (PI. 1/14), provenit dintr-un mormânt. Veriga este circulară în seç̧iune. Pe ea a fost introdus un pandantiv sferic decorat pe fiecare jumătate cu câte patru conuri din foiţă de bronz. De o parte și de alta a sa, în jurul verigii, pentru fixare, este înfăşurată sârmă simplă.

Bibliografie: Dumitriu 2001, 39. 107, Taf. $70 / 11$.

\section{Assezare}

I.3. Coconi (com. Mănăstirea, jud. Ilfov)

Punct: Căldarea; ansamblu: aşezare.

Cercel din cupru, din bordeiul nr. 29. Cercelul are veriga circulară în secţiune (Pl. 1/6). Montura centrală, a fost confecţionată prin lipirea a două semisfere. Zona centrală are lipite trei sârme filigranate. Decorul constă în opt protuberanţe în formă de paraboloid, câte patru pe fiecare jumătate.

\footnotetext{
${ }^{7}$ Dumitriu 200I, 14I, Taf. 48/16.

8 Jelovina 1976, T. XX/11-12.

9 Jelovina 1976, T. XL/4-5.

${ }^{10}$ Jelovina $1976, T$. LXI/1-2.
} 
La baza lor este câte un cadru circular de sârmă filigranată, iar spre vârf câte o mică granulă. Pe verigă, de o parte şi de alta a sa a fost înfaşurată o sârmă filigranată. În locurile în care aceasta se termină, au fost realizate două muluri de sârmă înfasşurată în formă de arc.

Bibliografie: Constantinescu 1972, 100, 247, PI. XIII/7; Dumitriu 2001, 39, 116, Taf. 87/7.

\section{Tezaure}

\section{I.4. Jiana Mare (com. Jiana, jud. Mehedinţi)}

Punct: necunoscut; ansamblu: tezaur.

Observaţii: piesa cu trei pandantive, este din argint, cu veriga ruptă $(\mathrm{Pl} .2 / 11)$. Monturile laterale, mai mici decât cea centrală. Pe pandantivele laterale, conurile sunt dispuse în partea centrală. Vârful lor a fost ornamentat cu granule. Pe verigă, între monturi este sârmă de argint filigranată. Pandantivul central, destul de deteriorat a fost la rândul său ornamentat cu conuri din foiţă de argint, dispuse pe două rânduri. Piesa a fost găsită în asociere cu monede emise în timpul lui Mircea cel Bătrân (1386-1418) şi Mihail I (1418-1420).

Bibliografie: Dumitriu 2001, 127, Taf. 39/3.

\section{Constanţa)}

\section{I.5. Păcuiul lui Soare (com. Ostrov, jud.}

Punct: cetatea bizantină; ansamblu: tezaur din nivel de locuire datat în cursul secolului al XIV-lea.

Cercel din argint aurit, cu trei monturi pe verigă $(\mathrm{Pl}$. 2/10). Aceasta din urmă a fost confecţionată dintr-o sârmă groasă pusă în două pe un anumit segment, apoi torsionată. În spaţiile libere rămase a fost introdus un fir filigranat. Montura centrală, de formă sferică a fost decorată pe centru cu un brâu de sârmă îndoitā în formă de spirală sau arc, flancată de câte o alta mai subţire, filigranată. Pe fiecare semisferă care formează pandantivul central sunt câte patru conuri din foiţă metalică, iar la baza şi la vârful lor este câte un cadru circular de sârmă filigranată, respectiv simplă. Între această montură și cele laterale, mai mici, este un spaţiu liber unde a fost înfasşurată o sârmă simplă care formează câteva spire. Pandantivele laterale, sferici, au fost confecţionaţi din plăcuţe circulare $(4+4)$. Fiecare dintre acestea are un cadru, iar în centru o mică granulă.

Bibliografie: Diaconu, Baraschi 1977, 125, fig. 98/2; Dumitriu 2001, 112, Taf. 20/2, 105/2.

\section{I.6. Voineşti (com. Voineşti; jud. Iaşi)}

Punct: neprecizat; ansamblu: tezaur.

Cercel de argint (Greutate $=18,18 \mathrm{gr}$.), cu trei monturi (una pierdută). Veriga ( $D=47,4 \mathrm{~mm}$; grosime $=3,6 \mathrm{~mm}$ ) este din sârmă de argint pusă în două şi torsionată, apoi decorată cu o alta mai subţire filigranată (Pl. 2/6). Aceasta din urmă, a fost introdusă prin bucla care s-a format prin îndoirea celei care formează veriga. Ea a fost împărţită astfel în două părţi egale care au fost introduse în spaţiul liber dintre sârmele torsionate. La intrarea în prima montură, ea a fost suprapusă de o alta filigranată, înfaşurată în jurul verigii.

Primul pandantiv $(\mathrm{D}=12,4 \mathrm{~mm}$, măsurat pe orizontală), gol în interior, parţial deformat, a fost confecționat din foiță de argint şi decorat cu pseudo-granule $(3+3$ rânduri). Sârma filigranată care fixează montura este şi ea la rândul său suprapusă de o alta mai simplă. Între montura unu şi doi este sârmă simplă, înfasşurată în jurul verigii. Ea este suprapusă parţial spre montura unu de o alta, tot simplă.

Montura 2 (cea centrală), biconică $(D=22$ $\mathrm{mm}, \mathrm{L}=28,5 \mathrm{~mm}$ ), goală în interior, este mai mare decât precedenta. A fost decorată cu opt conuri din foiţă de argint, câte patru pe fiecare jumătate. În partea lor superioară este câte un cerculeţ de sârmă simplă care formează un cadru în jurul bazei fiecărei granule lipite în vârf. Baza fiecărui con este înconjurată de un brâu de sârmă filigranată.

Între conurile decorative, spre partea centrală a pandantivului, sunt câte două granule $(8+8 ; \mathrm{D}=$ $3 \mathrm{~mm}$ ), iar spre capetele sale câte patru $(4+4)$. Între granulele din capete şi cele dinspre centrul monturii biconice au fost lipite câte o sârmă de argint filigranat, în așa fel încât se formează un decor floral (câte patru pe fiecare jumătate).

Între cele două emisfere sunt patru sârme filigranate alăturate. Vârfurile monturii biconice au fost la rândul lor decorate fiecare cu o mulură din sârmă simplă răsucită în formă de arc.

Piesa se află în colecţia M.N.I.R. cu nr. inv. 81399.

Bibliografie: Spinei 1994, 25, 124, 127, 455, fig. 21/9; Teodor 2003a, 151, 160, fig. 7/6, 161, fig. 8/7; Ofa 2009b, 187-188, 200, 207, PI. $3 / 5$.

\section{Descoperire intâmplătoare}

I.7. Drobeta-Turnu Severin (jud. Mehedinţi)

Punct: neprecizat, din teritoriul oraşului; ansamblu: necunoscut.

Cercel din argint ornamentat cu trei monturi, decorat în tehnica granulaţiei şi filigranului (PI. 3/1). Veriga este parţial ruptă, ceea ce îngreunează posibilitatea de a data ceva mai strâns piesa. Veriga, atât cât se păstrează, nu este din sârmă torsionată. Aceasta nu exclude însă ca partea pierdută să fi fost pusă în două şi torsionată, asemenea multor cercei cu trei monturi pe verigă. $O$ sferă laterală a fost pierdută. Cea păstrată este decorată în tehnica granulaţiei şi este mai mică decât cea centrală. Între monturi este o sârmă de argint filigranată înfăşurată în jurul verigii. $O$ alta similară este şi în partea cealaltă a monturii centrale. Aceasta din urmă este executată din foiţă de argint. În zona centrală sunt fixate patru sârme filigranate dispuse una lângă alta, 
de jur împrejurul monturii. La capete, lângă verigă este câte o mulură de sârmă înfășurată în spirală. Suprafaţa pandantivului central are ca decor principal opt piramide din foiţă de argint, câte patru pe fiecare jumătate. Vârful acestora a fost decorat cu granule $(3+1)$. Bazele piramidelor au fiecare câte un cadru de sârmă. Tot pe suprafaţa pandantivului, spre centru și spre capete, au fost fixate granule de argint care au la bază un cadru de sârmă. $37 / 35$.

Bibliografie: Dumitriu 2001, 39, 123, Taf.

\section{I.8. Isaccea (jud. Tulcea)}

Punct: Burg?; ansamblu: neprecizat.

Cercel confecţionat de bronz și argintat (Pl. $1 / 7$ ). Veriga este circulară în secţiune. Montura centrală, sferică este decorată pe fiecare jumătate cu câte patru conuri. La baza fiecăruia este un cadru circular din sârmă. De o parte şi de alta a sa a fost înfăşurată sârmă pentru fixxare şi câte un brâu sau mulură tot din sârmă (?).

Bibliografic: Dumitriu 2001, 108, Taf. 72/3 (în text trimiterea la ilustraţie este greşită, iar bibliografia de la pagina 108 nu se referă la piesa în discuţie).

\section{Il. Ucraina}

\section{Tezaur}

\section{II.1. Cernăuţi}

Punct: neprecizat; ansamblu: tezaur.

Pereche de cercei cu trei monturi pe verigă (Pl. 2/5). Veriga este din bară simplă, circulară în seç̧iune. Montura centrală, mai mare decât cele latcrale, este biconică. Pe centru are trei sârme care delimitează cele două jumătăți. Decorul constă în opt conuri de foiţă metalică $(4+4)$. La baza fiecăruia este un cadru de sârmă filigranată, iar în vârf este lipită o sârmă în formă de cerc, iar deasupra ei o granulă. Fiecare jumătate a celor două conuri care formează pandantivul central este împărţită în patru zone de câte un şir de granule. Acestea pornesc din vârf, prin spaţiul lăsat între ornamentele în formă de con şi se indreaptă spre centru. În zonele în care veriga trece prin pandantiv, este câte o mulură din sârmă îndoită în formă de arc. În jurul verigii, de o parte şi de alta a monturii centrale, a fost înfăşurată sârmă pentru fixare şi crearea unui spaţiu până la pandantivele laterale. Aceştia sunt sferici şi au fost decoraţi cu granule.

Bibliografie: Ćorović-Ljubinković 1954, 83-84, sl. 4; Spinci 1994, 127, 453, fig. 19/4-5.

\section{Serbia}

Tezaur
III.I. Braničevo (opšt Braničevo)

Punct: Rudine; ansamblu: tezaur.
Pereche de cercei cu trei monturi pe verigă (Pl. 2/1-2). Veriga este din bară simplă, circulară în secţiune. Montura centrală, mai mare decât cele laterale, este de formă sferică. Pe centru are o mulură de granule flancată de patru sârme filigranate, câte două pe fiecare parte. Decorul celor două jumătăţi care compun pandantivul constă în opt conuri de foiţă metalică (4+4). La baza fiecăruia este un cadru de sârmă filigranată, iar în vârf sunt lipite granule $(3+1)$. În spaţiul rămas liber dintre conuri, au fost realizate tot din granule mici triunghiuri cu baza lipită de sârmele filigranate care flanchează mulura. Spre verigă decorul este executat similar, dar triunghiurile sunt poziţionate invers. De o parte şi de alta a monturii centrale, în jurul verigii a fost înfăşurată sârmă filigranată pentru decor, o mai bună fixare şi pentru a crea un spaţiu între pandantive. Monturile laterale sunt tot sferice şi au fost decorate similar. Singurul element care nu se regăseşte ca decor este mulura centrală de granule, iar triunghiurile au fost executate dintrun număr mai mic de granule.

Bibliografie: Popović, Ivanišević 1988, 153 , 154, sl. 24/2-3.

\section{Descoperire intâmplătoare (?)}

\section{III.2. Kalna (opšt Knjaževac)}

Punct: ? Autoarea studiului plasează localitatea lângă Pirot, dar actual Kalna aparţine de opština Knjaževac.

Pereche de cercei de argint cu veriga simplă şi trei monturi sferice (PI. 2/3-4). Pandantivele laterale sunt puţin mai mici decât cel central, dar au fost decoraţi la fel. Primul cercel are o parte a verigii lipsă şi a fost ornamentat cu opt conuri de foif̧ă de argint, câte patru pe fiecare jumătate. Vârfurile lor au câte patru granule $(3+1)$, iar bazele au un cadru de sârmă. Partea centrală a fost şi ea ornamentată cu patru spire de sârmă filigranată. Acelaşi decor se întâlneşte şi în spaţiul dintre monturi. Pandantivul central a fost identic, dar mai mare. D. păstrat $=55$ $\mathrm{mm}, \mathrm{D}$ monturii centrale $=18 \times 18 \mathrm{~mm}$. Al doilea cercel are un pandantiv lipsă. Este decorat similar cu precedentul. D. păstrat $=47 \mathrm{~mm}, \mathrm{D}$ monturii centrale $=18 \times 18 \mathrm{~mm}, \mathrm{D}$ monturilor laterale $=13 \times 13 \mathrm{~mm}$, D. verigii $=3,5 \mathrm{~mm}$.

Bibliografie: Ćorović-Ljubinković 1954,86 , sl. 9.

\section{Macedonia}

\section{Descoperire întâmplătoare}

\section{IV.1. Prilep (opšt. Prilep)}

Punct: Varoș, Markovi Kuli; ansamblu: neprecizat.

Cercel din argint, de tip cuman (PI. 2/9), decorat în tehnica granulaţiei şi filigranului. Veriga 
este executată din sârınă de argint pusă în două şi torsionată, decorată cu o alta mai subţire, filigranată. Monturile laterale, sferice, sunt ajurate. Pentru fixare pe verigă s-a utilizat sârmă filigranată. Montura centrală, mai mare, este biconică. La baza conurilor se află o mulură de granule de argint flancată de două cercuri de sârmă filigranată, paralcle şi distanţate. Pe fiecare con se află alte patru mai mici, decorate în vârf cu patru granule dispuse în formă de piramidă. Bazele conurilor sunt înconjurate de câte un cerc de sârmă filigranată. Suprafata fiecărui con care formează montura centrală este decorată cu triunghiuri de granule. lipite în spaţiile libere, patru la bază şi patru la vârfuri. $\mathrm{D}=53 \times 50 \mathrm{~mm}$. D montura centrală $=39 \times$ $25 \mathrm{~mm}, \mathrm{D}$ monturi laterale $=14 \mathrm{~mm}$, grosimea verigii $=5 \mathrm{~mm}$. Piesa se află la Muzeul de Artă Decorativă din Bclgrad.

Bibliografie: Corović-Ljubinković 1954, 88, sl. 13; Maneva 1992, 195. Pl. 21/58/50; Oła 2008, 97; Ota 2010, 121, PI. 3/3, 126.

\section{Bulgaria}

\section{Necropola}

\section{Sofia)}

V.1. Skravena (obšt. Botevgrad, oblast

Punct: tumulul nr. I al necropolei trace de lângă Skraveva; ansamblu: necropolă de înhumaţie.

Mormântul 42. Pereche de cercei din argint aurit cu veriga simplă şi trei monturi ( $\mathrm{Pl} .3 / 2-3$ ). Pandantivele laterale, mai mici decât cel central, sunt sferici decoraţi cu pseudo-granule. Între monturi este o sârmă filigranată înfăşurată în jurul verigii. Aceasta din urmă. a fost decorată în partea centrală cu o sârmă buclată flancată de altele două filigranate. La capete, lângă verigă este câte o mulură de sârmă înfăşurată în spirală. Suprafaţa pandantivului central are ca decor principal opt piramide, câte patru pe fiecare jumătate. Vârful acestora a fost decorat cu granule $(3+1)$. Bazele piramidelor au fiecare câte un cadru de sârmă filigranată. Tot pe suprafaţa pandantivului, spre centru şi spre capete, au fost fixate granule de argint care au la bază un cadru de sârmă. Din mormânt provine şi o monedã din timpul tarului loan Asan al II-lea (1218-1241).

Bibliografic: Agrè 1990, 23, 24, obr. 17.

\section{Tezanre}

\section{V.2. Divdiadovo (oblast Sumen)}

Punct: carieră; ansamblu: tezaur.

Pereche de cercei de aur cu veriga de sârmă simplă, două monturi sferice şi altele trei mai mici (Pl. 1/12-13). Monturile centrale au fost decorate pe fiecare jumătate cu patru decoruri în formă de paraboloid. Partea lor superioară are lipită câte o granulă. La baza lor este câte un cerc de sârmă filigranată, de jur împrejur. Spaţiul rămas liber este decorat cu granule. Partea mediană a monturilor este omamentată cu sârmă fixată în jurul lor. De o parte şi de alta a celor două pandantive sferice, în jurul verigii a fost înfăşurată două sârme. În părţile laterale, în punctul în care se termina acest ornament, a fost introdusă câte o montură semisferică. Tot pe verigă a mai fost introdus un al treilea decor, la o mică distanţă. A doua piesă are o parte a verigii ruptă.

Pereche de cercei de aur cu veriga de sârmă simplă, o montură centrală, două mici laterale şi o alta distanţată (Pl. 1/10-11). Una din piese are veriga ruptă. Cealaltă, păstrată, are o buclă la un capăt. Montura centrală este decorată aproape similar cu perechea precedentă. Diferenţele se observă doar în partea mediană care a fost decorată cu tubulete distanţate, confecționate din sârmă spiralată. Spaţiul rămas liber dintre paraboloide a fost umplut cu mici cerculețe de sârmă. Restul decorurilor sunt similare ce perechea precedentă.

Bibliografic: Mollov 1927-1928, 301, obr. 120, rândul doi şi trei, 302 .

Varna)

V.2. Dobrogled (obšt. Aksakovo, oblast

Punct: Paradžik; ansamblu: tezaur.

Pereche de cercei din aur ( $\mathrm{Pl}$. 1/8-9), similari ca execuţie cu exemplarul de la Coconi.

Bibliografie: Kuzev 1961, 14, obr. 1; Constantinescu 1972, 100; Neševa 1985, 117, Tabl. $5 / 4$.

V.3. Dragijevo (obšt. Lyaskovets, oblast Veliko Tărnovo)

Punct: neprecizat; ansamblu: tezaur ${ }^{11}$.

Cerceii sunt pereche, din argint, ornamentaţi în tehnica granulaţiei şi filigranului ( $\mathrm{PI} .3 / 2-3$ ). Veriga a fost confecţionată din sârmă pusă pe un anumit segment în două şi apoi torsionată. Decorul ei a fost realizat cu sârmă filigranată. Pe ea au fost introduşi trei pandantive, doi mai mici, sferici şi ajurați, dispuşi în lateralele unuia central mai mare, biconic. Decoraf̧iile sale sunt piramidale, câte patru pe fiecare jumătate. Vârfurile sunt ornamentate fiecare cu patru granule, trei la bază şi una peste ele. În zona sa mediană este o mulură de granule. Pe suprafaţa fiecărui con, la baze, sunt triunghiuri de granule, din al căror vârf pleacă spre verigă câte

\footnotetext{
"Piescle aparł̧in unui tezaur mai mare, care cuprindea şi un al treilea cercel de acelaşi tip (cuman), însá cu alte caracteristici ornamentale, douã brātāri din sârme împletite şi o altā pereche de cercei. Din tezaur lăceau parte şi monede emise în timpul lui Mihail Sişsman (1322-1330). Andronic al II-lea şi Mihail al IX-lea (1282-1328).
} 
un şir, împărțind astfel montura în suprafete egale.

Bibliografie: Ćorović-Ljubinković 1954, 87; Filow 1919, 41, fig. 37, 34 (rândul doi, piesele din stânga şi din dreapta); Oţa $2010,121, \mathrm{Pl} .3 / 4-5$, $124-125$

\section{V.4. Nikopol (obšt. Nikopol, oblast Pleven)}

Punct: Harmanlăka

Cercel de aur cu trei monturi inegale (PI. $3 / 10$ ). Veriga este confecţionată dintr-o sârmă pusă în două şi torsionată. A fost omamentată cu altă sârmă mai subţire filigranată. În partea centrală este o montură confecţionată din două piramide de foiţă de aur puse bază în bază. Laturile sale lungi au fost decorate fiecare cu o sârmă spiralată. De o parte şi de alta a fiecăreia, este câte una filigranată. Faţetele sale au fost decorate ca motiv principal cu un tetraedru din plăcuțe triunghiulare ornamentate cu un cadru de sârmă filigranată. În apropierea bazei, pe fiecare plăcuţă este câte o granulă. Pe suprafaţa plăcuțelor care formează piramidele, au fost lipite câte patru granule alăturat, în linie, dinspre vârf spre baza tetraedrelor. Spaţiile rămase libere au fost umplute cu cerculeţe de sârmă simplă. În fiecare colţ al triunghiurilor care formează piramidele a fost montată o granulă. Baza fiecărei piramide este decorată cu o sârmă filigranată, iar la colţuri cu câte un tub de sârmă. Vârfurile piramidelor au fost la ràndul lor decorate cu o mulură de granule. Spaţiul dintre montura centrală și cele laterale a fost umplut cu sârmă filigranată înfăşurată în jurul verigii. Monturile laterale sunt mai mici, similare ca dimensiune şi decor. Acestea au fost confecţionate fiecare din două jumătăţi compuse din petale de foiţă de aur, decorate cu un cadru de sârmă filligranată. În centrul fiecărei petale este o granulă înconjurată la bază de o sârmă. Pe centru este o bandă încadrată pe lungime de câte o sârmă filigranată. Pe ea au fost lipite mici tuburi din sârmă filigranată. De o parte şi de alta a monturilor laterale este câte o mulură de sârmă spiralată.

Bibliografie: ArcheologijaSof, 25, 1983, 3, copcria.

\section{Descoperiri de tip neprecizat}

\section{V.5. Stara Zagora (oblast Stara Zagora)}

Punct: neprecizat; ansamblu: tezaur.

Cercel din aur cu trei monturi inegale ( $\mathrm{Pl}$. 3/4). Veriga este confecţionată dintr-o bară simplă, dar groasă. Montura centrală este biconică. Decorul său principal constă în câte patru piramide din foiţă de metal. Baza lor are un cadru de sârmă filigranată. Vârfurile au un decor din trei granule lipite una de alta şi suprapuse de o a patra. În apropierea bazei conurilor a fost lipită câte o sârmă Ciligranată de jur-împrejur. Spaţiul rămas liber a fost decorat cu patru cerculeţe de sârmă fixate perpendicular pe baza conurilor. La vârfuri se află câte o mulură de sârmă spiralată. Monturile laterale sunt mai mici, din foiţă de aur. Pe centru fiecăreia şi pe laterale este o mulură de sârmă spiralată. Spaţiul dintre monturi este nedecorat. La mică distanță, în exteriorul monturilor laterale, se află alte douã formate tot din sârmă spiralată.

Bibliografie: ***Istoria na Bălgaria. Tom treti. Vtora Bălgarska dăržava, 133, fig. 3.

\section{V.6. Şumen (oblast Şumen)}

Punct: neprecizat; ansamblu: tezaur.

Cercel din aur cu trei monturi inegale (PI. $3 / 5$ ). Veriga este confecţionată dintr-o bară simplă, dar groasă. Montura centrală este confecţionată din două piramide de foită de aur. Fiecare faţetă are un cadru triunghiular de sârmă filigranată, iar în interiorul lor sunt granule distanţate. Decorul principal constă din câte patru piramide din foiţă de aur. Pe suprafaţa fiecărei faţete este câte un cadru de sârmă filigranată. În vârful fiecărei piramide este câte o granulă. De o parte şi de alta a monturii centrale este câte o mică mulură de sârmă spiralată. Monturile laterale sunt mai mici, similare ca dimensiune şi decor. Acestea au fost confecţionate fiecare din două jumătăţi compuse din petale de foiţă de aur, decorate cu un cadru de sârmă filigranată. Pe suprafaţa fiecărei petale sunt câte cinci granule distanţate dispuse în jurul unei o a şasea granulă aflată în centru. Spaţiul dintre monturi a fost decorat cu sârmă filigranată. După cea de-a doua montură laterală a fost înăşurată în jurul verigii o altă sârmă filigranată, la al cărei capăt este un alt decor din acelaşi material care sugerează o mulură.

Bibliografie: ***Istoria na Bălgaria. Tom treti. Vtora Bălgarska dăržava. 230, fig. 2, 231.

\section{V.7. Punct nespecificat din Bulgaria.}

Cercel cu veriga din sârmă torsionată $(\mathrm{Pl}$. 3/9). Monturile laterale lipsesc. De o parte şi de alta a celei centrale a fost înfaş̧urată sârmă în jurul verigii. Montura centrală este confecţionată din două piramide de foiţă metalică, puse bază în bază. în laterale sunt două muluri. Baza piramidelor a fost decorată la colţuri cu tuburi de sârmă spiralată. Pe triunghiurile care formează piramidele au fost lipite granule izolate. Fiecare faţetă a celor două piramide a fost decorată cu o alta mai mică. În vârfuri au fost fixate câte o granulă. Pe suprafeţele lor au fost lipite granule, aproximativ în partea centrală.

Bibliografie: Georgieva 1961, 4, sl. 1/11.

\section{Croaţia}

\section{Necropole}

VI. l. Biskupija (županija Šibenik-Knin)

Punct: Crkvina; ansamblu: necropolă.

Cercel cu veriga din sârmă simplă (PI. 1/5). Montura în formă de elipsoid, a fost decorată pe centru cu patru paraboloide de foif̧ă de metal. În 
partea lor superioară este aplicată o granulă a cărei bază este înconjurată de o sârmă simplă. Partea inferioară a lor a fost decorată cu un cerculeţ de sârmă fïligranatā, iar de lângă ele pleacă alte triunghiuri din granule. De o parte și de asta a paraboloidelor, la mică distantã, sunt câte un cadru circular de granule. De o parte şi de alta a lor sunt alte triunghiuri executate tot din granule. Capetele monturii au fost decorate şi ele tot în tehnica granulaţiei.

Cercel cu veriga din sârmă simplă ( $\mathrm{Pl}$. 1/4). Montura biconică, a fost decorată în tehnica granulaţiei şi filigranului. Ornamentul constă în trei rânduri de paraboloide de foită de metal, iar de o parte şi de alta cu două rânduri de câte trei. Acestea din urmă au fost fixate exact în spaţiile lăsate libere dintre paraboloidele care formează rândul central. În partea lor superioară este aplicată o granulă a cărei bază este înconjurată de o sârmă filigranată. Spał̧iul rămas liber a fost decorat cu cerculeţe de sârmã filigranatǎ. În exteriorul decorului realizat cu paraboloide, de o parte şi de alta a sa, pe montură, sunt câte două cerculeţe de sârmă filligranată lipită de jur-împrejur şi distanţate.

Bibliografic: Jelovina 1976, 21-24, 97-99, Г. XVIl/5-6

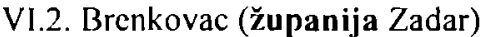

Punct: Podgrađe; ansamblu: necropolă.

Montură de cercel similară $(\mathrm{Pl}$. 1/3) cu picsele de la Bribir-Vratnice, dar cu rândurile de paraboloide de câte trei $(3+3+3)$, asemenea exemplarului 2 de la Biskupija-Crkvine.

Bibliografie: Jelovina 1976, 37, 87-99, T. $\mathrm{LII} / 14$.

\section{VI.3. Bribir (̌̌upanija Šibenik-Knin)}

Punct: Vratnice; ansamblu: necropolă înhumaţie.

Mormântul 63; inventar: doi cercei din bronz. (Pl. |/I-2). cu veriga din sârmă simplă. Montura în formă de elipsoid, a fost decorată 12 paraboloide de foił̧ă de metal $(4+4+4)$, dispuse similar cu piesa nr. 2 de la Biskupija-Crkvine, adică pe trei rânduri. În partea lor superioară este aplicată o granulă a cărei bază este înconjurată de o sârmă simplă. Partea inferioară a lor a fost decorată cu un cerculet de sârmă. Spaţiul dintre paraboloide este decorat cu sârme filigranate dispuse în "X" care formează cadre rombice.

Bibliografie: Jelovina 1976, 35-36, 97-99, T. XI,VIII/12-13; ***Nakit na thu sjeverne Dalmacije od prapovijesti do danas, Izložba, Zadar, 1981, 190, sl. 3/14, p. 193, T. 31 , stânga jos.

\section{Tipul descoperirilor}

Exemplarele studiate provin din diverse tipuri de descoperiri, anume necropole (Cuptoare, Bribir, Biskupija, Biljane, Skravena), tezaure (Dragijevo, Păcuiul lui Soare, Braničevo, Voineşti, Cernăuıi, Jiana Mare, Nikopol, Dobrogled, Divdiadovo), aşezări (Coconi). Alte piese au fost găsite întâmplător (Prilep, Drobeta-Turnu-Severin, un punct nespecificat din Bulgaria?).

Tipurile de piese pe care apar decoraţiile analizate sunt diverse.

Cele mai simple exemplare sunt cele care au o sferă simplă pe verigă, fixată de-o parte şi de alta cu sârmă (Enisala).

Urmează sfere introduse pe o verigă din sârmă simplă, fixate în acelaşi mod cu exemplarele precedente. Spre capetele sârmei care are rol de fixare a monturii, este o altă sârmă spiralată fixată în jurul verigii (Coconi, Isaceea, zona Varna).

\section{Caracteristici de execuţie}

Materialele utilizate pentru confecţionarea lor au fost bronzul, argintul şi aurul.

Pentru a simplifica dar şi a sistematiza discuţia a supra cerceilor, am preferat analiza separată a verigilor, pandantivelor laterali şi a celor centrali.

1. Verigile sunt de două feluri: simple (Skravena, Stara Zagora, Sumen, Braničevo, Kalna, Cernăuti, Coconi, Isaccea, Dobrogled, Divdiadovo, Enisala, Bribir, Biskupija, Brenkovac) şi din sârmă torsionată (Prilep, Voineşti, Păcuiul lui Soare, Cuptoare, Dragijevo şi o piesă cu loc de descoperire nespecificat din Bulgaria). În cazul piesei descoperite la Drobeta-Turnu Severin nu putem spune cu certitudine ce fel de verigă a avut, o parte din ea fiind ruptă şi pierdută, iar partea păstrată are trei pandantive pe verigă. Se adaugă faptul că astfel de piese, chiar dacă au avut veriga din sârmă pusă în două şi torsionată, aceasta se realiza de regulă doar parţial, în zona vizibilă, ori aici chiar ea lipseşte.

2. Pandantivele laterale sau ornamentele laterale, acolo unde ele există, sunt cunoscute în mai multe variante. 
Cel mai simplu decor amplasat în lateralele pandantivului central constă în buclarea unei sârme sau îndoirea sa în spirală, după care se înfăşura în jurul verigii la o anumită distanţă de montura centrală. Astfel de situaţii sunt observate la podoabele de la Coconi şi cele de la Dobrogled. O altă posibilă piesă pare a fi cea de la Isaccea. Toate aceste exemplare se asociază cu verigi simple, iar pandantivul central este decorat cu paraboloide de foiţă de aur sau bronz.

Un caz asemănător cu precedentul, este observabil la cerceii de la Divdiadovo, unde a fost introdusă o mică montură semisferică având rolul de a acoperi capătul sârmei înfăşurate în jurul verigii. La o mică distanţă a mai fost fixată o altă decoraţie similară.

O a treia situaţie este aceea când pandantivele laterali sunt decoraţi similar cu cel central, dar au dimensiuni sensibil mai mici (Braničevo şi Kalna). Ei se asociază cu verigi simple.

Un alt grup de podoabe este cel format din piese care au pandantivii laterali sferici, ajurați (Prilep, Cuptoare, Dragijevo). Fără excepţic au apărut pe cercei cu veriga din sârmă torsionată.

Cel de-al cincilea grup, cuprinde acele pandantive decorą̧i cu pseudo-granule sau granule. Aici se disting două sub-variante. Prima este aceea a pieselor care au întreaga suprafaţă decorală (Cernăuti, Dragijevo, Skravena, Drobeta-Turnu Severin). Cea de-a doua este cea a pieselor care au doar zona centrală decorată (Voineşti). Acesta are bune analogii cu pandantivele unui alt cercel descoperit în Moldova, la Oleleni ${ }^{12}$. Acesta a fost datat cu monede emise în special la sfârşitul secolului al XIII-lea, ultima emisiune fiind din 1290.

Următoarea grupă este formată de pandantivele laterale de formă sferică, realizaţi din plăci circulare lipite între ele (Păcuiul lui Soare).

Urmează acele piese în formă de elipsoid, ca de exemplu la Jiana Mare.

O ultimă grupă este formată din acele monturi confecţionate din discuri sau foiţe metalice în formă de petală decorate în tehnica granulaţiei şi filigranului. Şi aici se observă două sub-variante. Prima o constituie cercelul de la Sumen, iar cea de-a doua cel de la

12 Teodor 2003b, 168, 174, fig. 2/6, 175, fig. 3/6.
Nikopol. Verigile pe care au fost montaţi sunt diferite ca mod de execuţie.

În cazul unei alte piese provenite din Bulgaria, pandantivele lipsesc, deşi foarte probabil ei au existat.

Alte câteva piese au dispus şi de un al treilea tip de decor. Acestea au fost de dimensiuni reduse şi sunt poziţionate în exteriorul monturilor laterale. Este vorba de piesele descoperite la Şumen şi Stara Zagora. În ambele cazuri apare pe cercei cu veriga simplă.

3. Pandantivii centrali, fuind şi cei mai mari, necesită o discuţie mai amănunţită. În primul rând se constată o mare diversitate a lor din punct de vedere al formelor. Aceștia pot fi sferici (Braničevo, Kalna, Păcuiul lui Soare, Coconi, Isaccea, Dobrogled, Enisala, Divdiadovo), biconici (Cuptoare, Cernăuti, Voineşti, Prilep, Stara Zagora, Drobeta-Turnu Severin, Skravena, Biskupije), în formă de elipsoid (Jiana Mare, Biskupija, Brenkovac, Bribir, Dragijevo), ori în forma a două piramide patrulatere regulate puse bază în bază (Sumen, Dragijevo, localitate neprecizată din Bulgaria).

\section{Decorul conic}

A fost observat pe două tipuri de cercei. Din punct de vedere numeric şi al repartiţiei teritoriale, este cel mai răspândit.

I.1. Acest decor apare iniţial pe cercei cu pandantiv sferic. În sud-estul Europei, este prezent pe o piesă de la Enisala (PI. 1/14). Tipul de verigă este simplu. Alte decoruri secundare lipsesc. Analogiile duc spre spaţiul controlat de către populaţiile turkice din secolele XI-XII ${ }^{13}$.

I.2. Un alt tip de cercei pe care apare acest decor este cel cu trei monturi pe verigă.

I.2.1. Un prim sub-tip este cel al exemplarelor cu veriga simplă (Braničevo, Kalna şi Cernăuti). În acest caz se disting două variante.

I.2.1.1. Prima dintre ele este reprezentată de cerceii care au pandantivul central de formă sferică (Braničevo şi Kalna). Pe lângă decorul din conuri, în acest caz mai apar şi motive secundare, realizate în tehnica granulaţiei şi filigranului (PI. 2/1-2, 3-4).

Pandantivele laterale sunt similari celui central, însă de dimensiuni sensibil mai mici.

Geografic este vorba de zona de la sudul Dunării Mijlocii. Cronologia absolută pentru

\footnotetext{
${ }^{13}$ Pletneva $1981,240,259$, rus. 82/99, 261. rus. 84/1.
} 
piesele din spaţiul central balcanic indică sfârşitul secolului al XIII-lea şi eventual începutul celui următor.

I.2.1.2. Varianta cerceilor cu pandantiv central biconic este reprezentată de exemplarele de la Cernáuti (Pl. 2/5). Din punct de vedere stilistic se deosebesc de toate celelalte piese, ceea ce indică un atelier diferit.

1.2.2. Un al doilea sub-tip este constituit din acele piese care au veriga din sârmă pusă în două pe un anumit segment şi torsionată (Voineşti, Cuptoare, Prilep, Păcuiul lui Soare și Jiana Mare). În funcţie de forma pandantivului central se disting următoarele variante:

1.2.2.1. Piese cu pandantivul central biconic (Voineşti, Cuptoare, Prilep). Din punct de vedere ornamental se disting trei subvariante.

1.2.2.1.a. Prima dintre ele este reprezentată de exemplarul de la Voinești (PI. $2 / 6$ ), decorat suplimentar cu granule şi sârmă filigranată. La baza conurilor, în punctul de îmbinare, a fost montată o sârmă spiralată flancată de altele două filigranate.

I.2.2.1.b. A doua o constituie piesele din M. 189 de la Cuptoare (Pl. 2/7-8). Aici decorul suplimentar este dispus între conurile ornamentale şi constă în triunghiuri de granule. În zona centrală a pandantivului sunt patru spire alăturate se sârmă filigranată.

1.2.2.1.c. Cel de-al treilea exemplar şi subvariantǎ a fost descoperit la Prilep (PI. 2/9) şi este decorat similar cu cerceii de la Cuptoare (PI. 2/7-8). Singura diferență este în zona centrală, unde două dintre spirele de argint filigranat au fost înlocuite cu o bandă metalică pe care este lipit un brâu de granule.

La acești cercei, monturile laterale sunt cunoscute în două variante. Prima este executată din foiţă de argint, din două semisfere şi decorată cu pseudo-granule (Voineşiti), iar cea de-a doua din două semisfere ajurate (Cuptoare, Prilep).

1.2.2.2. Piese cu pandantivul central sferic (Păcuiul lui Soare). Cele laterale, mai mici, sferice, au fost confecţionate din plăcuţe circulare lipite între ele ( $\mathrm{Pl} .2 / 10)$.

1.2.2.3. Piese cu pandantivul central clipsoidal (Jiana Mare), decorat cu trei rânduri de conuri. Pandantivele laterale sunt tot elipsoidale (Pl. 2/11).

\section{Decorul piramidal}

Este observat pe piese descoperite la Dragijevo, Drobeta-Turnu Severin, Sumen, Stara Zagora şi Skravena.

Din punct de vedere al tipologiei verigilor, se constată că este vorba de exemplare executate din sârmă simplă (Drobeta-Turnu Severin şi Skravena) şi sârmă torsionată (Dragijevo). Toate piesele au trei pandantive, câte unul central şi doi laterali. Pandantivele centrale sunt, în toate cele trei cazurile, biconici. La niciuna dintre piese, decorul nu este identic. Cele mai mari similitudini sunt între piesele de la DrobetaTurnu Severin (PI. 3/1) şi cele de la Skravena (PI. 3/2-3). Singurul element care diferenţiază pandantivele centrale sunt decorul din zona de îmbinare a conurilor. Dacă în primul caz el constă în patru spire din sârme filigranate, în cel de-al doilea, pe centru este o sârmă spiralată strâns, flancată de câte una filigranată. Pentru piesele de la Dragijevo (PI. $3 / 6-7$ ), decorul de la baza conurilor constă într-un brâu de granule. Spaţiul dintre piramidele decorative este ornamentat cu triunghiuri de granule puse bază în bază. Din vârful fiecăruia pleacă o linie de granule spre vârful conurilor care formează montura centrală.

Pandantivele laterale, mai mici, sunt în toate cele trei descoperiri, sferici. Ca mod de execuţie sunt fără excepţie diferiţi. La Dragijevo ei sunt ajuraţi, la Drobeta-Turnu Severin, decoraţi cu şiruri paralele de granule, iar la Skravena au fost ornamentaţi cu pseudogranule. Se poate observa persistenţa în cele trei cazuri a motivului şirurilor paralele, dar executate de fiecare dată în mod diferit.

Din punct de vedere al repartiţiei teritoriale, se poate observa că sunt piese produse în sudul Dunării, în spaţiul actual al Bulgariei. Doar sporadic au pătruns la nordul fluviului, probabil prin comert. Foarte probabil aceste piese aparţin unor ateliere diferite. Din punct de vedere decorativ, între exemplarele de la Drobeta-Turnu Severin şi cele de la Skravena $^{14}$ nu se observă diferenţe semnificative. Cel mai probabil piesele au fost produse cel mai târziu spre finalul secolului al XIII-lea. În ceea ce priveşte piesele de la

\footnotetext{
${ }^{14}$ Este de precizat faptul cã în necropola aceasta au fost descoperite monede emise în timpul lui Ioan Asan al IIlea (1218-1241).
} 
Dragijevo, pot fi datate la finalul secolului al XIII-lea şi începutul secolului al XIV-lea.

III. Decorul în formă de paraboloid apare pe trei tipuri de cercei. Este şi el destul de puţin întâlnit, fiind observabil la piesele descoperite la Bribir, Biskupija, Divdiadovo, Brenkovac, Isaccea, Coconi şi Dobrogled. Din start se poate observa faptul că se conturează două areale de distribuţic. Primul este reprezentat de zona Dalmaţiei, iar cel de al doilea de teritoriul de la Dunărea de Jos. Cronologia lor relativă indică şi ea două mari grupe. Cea mai timpurie se leagă de regiunea de coastă a Croaţiei unde aceste piese sunt databile în secolele IX-X. La Dunărea de Jos, piesele sunt mai târzii şi au fost datate în sccolul al XIV-lea.

Principala caracteristică a lor constă în veriga din sârmă simplă, indiferent de spaţiul geografic sau cronologie.

Diferenţele apar în momentul analizei pandantivului şi în anumite cazuri a decorurilor laterale.

III.1. Astfel, decorul analizat apare pe pandantive sau monturile elipsoidale de la Bribir, Biskupija şi Brenkovac. În ceea ce priveşte dispunerea sa (n. n. a decorului principal), se disting următoarele sub-tipuri:

III.1.l. Omament format din trei rânduri de conuri (Bribir, Biskupija, Brenkovac). La acesta se adaugă suplimentar motive realizate în tehnica filigranului.

III.1.2. Ornament format dintr-un singur rând de conuri dispuse în zona centrală (Biskupija). Suplimentar pe suprafaţa monturii au mai fost realizate şi decoruri în tehnica granulaţiei. şiruri şi triunghiuri.

III.2. Un al doilea tip de pandantiv central decorat cu motivul paraboloidului este cel sferic (Coconi, Isaccea, Divdiadovo şi Dobrogle(d). În acest caz, de o parte şi de alta a monturii, după ce sârma de fixare a fost înăşurată, se realiza o mulură de sârmă spiralată.

În funcţie de decorurile suplimentare şi materialul de execuţie, putem vorbi de patru subtipuri:

III.2.1. Coconi (bronz şi spire de sârmă filigranată în zona diametrului maxim).

III.2.2. Isaccea-Burg (bronz argintat).

III.2.3. Dobrogled-Aksakovo (aur și spire de sârmă filigranată în zona diametrului maxim).
III.2.4. Divdiadovo (aur, cerculeţe de sârmă pe suprafaţa pandantivului central, mici muluri simple pe verigă şi tuburi de sârmă spiralată distanţate în zona diametrului maxim).

III.3. Similar a mai fost decorată o pereche de cercei de aur descoperiţi în tezaurul de la Divdiadovo, decorată cu două pandantive de dimensiuni egale, două ornamente laterale şi un al cincilea pe verigă.

Cronologia pieselor este relativ unitară, ele fiind datate în cursul secolului al XIV-lea pe baza contextului stratigrafic şi a tipologiei.

IV. Tetraedrul ca decor al pandantivului a fost înregistrat momentan doar pe o piesă descoperită la Nikopol. Acesta a fost ornamentat similar cu cel de pe piesele descoperite la Dragijevo, Sumen şi de pe un alt cercel provenit dintr-o localitate din Bulgaria.

Cronologia relativă este oferită de poziţia stratigrafică a pieselor în timpul cercetărilor arheologice şi de similitudinile de execuţie a pieselor ${ }^{i 5}$. În cele ce urmează o voi discuta doar pentru acei cercei care nu au putut fi încadraţi cronologic pe baza monedelor.

Pe baza situaţiei stratigrafice au fost încadrate piesele de la Păcuiul lui Soare, anume la mijlocul veacului al XIV-lea. La fel s-a procedat şi cu piesele provenite din necropolele din spaţiul dalmat. Acestea au fost datate în special în veacurile IX-X, cu unele posibile prelungiri şi în secolele XI-XII. În cazul cerceilor avuţi în discuţie, au fost atribuiţi secolelor IX-X.

La Coconi, piesa a fost datată în secolul al XIV-lea, ceea ce corespunde cronologic cu perechea de cercei similari de la Dobrogled, dataţi la mijlocul secolului amintit.

Un prim amănunt este modul de execuţie al verigii. În cazul pieselor analizate aici, nu avem decât două tipuri, anume cele din sârmă simplă şi cele din sârmă pusă parţial în două şi torsionată. Ca decor suplimentar, aceasta din urmă putea să mai aibă o altă sârmă mai subţire filigranată, înfăşurată printre spaţiile libere rămase prin torsionarea celei mai groase. Cronologia lor este destul de bine cunoscută. Reamintim doar că veriga din sârmă pusă în două şi torsionată, a început să fie utilizată

\footnotetext{
${ }^{15}$ Se impune o precizare, anume cã în analiza de fațā nu iau în disculie orlevrăria din veacul al XVI-lea care este aproape fundamental diferită de cea a secolelor precedente.
} 
doar în ultimul sfert al secolului al XIII-lea. În cazul celorlalte piese, ea este de regulă mai timpurie. $\mathrm{Nu}$ trebuie însă exclusă nici posibilitatea ca unele exemplare de verigi simple să mai fie utilizate și în secolul al XIVlea sau chiar în cel de-al XV-lea, ca de excmplu cerceii de la Coconi, Isaccea, Dobrogled şi Dvidiadovo. Acestea sunt însă cazuri izolate şi se poate observa că apar doar la anumite tipuri de cercei.

Un bun element de datare în constituie prezenł̧a pandantivelor sferici ajuraţi. În cazul exemplarelor noastre, la care se asociază doar cu verigi din sârmă torsionată. ei pot fi atribuiţi sfârşitului secolului al XIII-lea şi secolului al XIV-lea ${ }^{16}$ (Prilep, Cuptoare).

Tot pe baza cronologiei relative se pot aduce completări în datarea piesei de la Voineşti. Dată fiind asocierea dintre veriga torsionată şi modelul decorativ al monturii centrale exccutat cu sârmă filigranată, această piesă poate fi datată la sfârşitul secolului al XIII-Ica ${ }^{17}$.

Pentru datarea piesei de la Stumen (Pl. $3 / 5$ ), se poate lua în considerafie modul de execulfie al monturilor laterale, anume din plācuţe decorate cu granule şi încadrate de o sârmă filigranată. Astfel de piese se regăsesc în special în necropola datată în cursul secolelor XIII-XIV de la Kaliakra ${ }^{18}$.

Cronologia absolută este cunoscută doar pentru un număr limitat de piese. Este vorba de tezaurele de la Dobrogled, Jiana Mare, Dragijevo, Braničevo si Skravena. Tezaurul de la Jiana Mare conţinea monede emise în vremea lui Mircea cel Bătrân (13861418) şi a lui Mihail I (1418-1420), iar cel de la Dobrogled a fost datat cu monede sârbeşti din vremea lui Ştefan Duşan (1331-1355), contramarcate după anul $1346^{19}$. În cazul celui descoperit la Braničevo, în afara pieselor de podoabă mai existau monede emise în timpul lui Jacopo Contarini (1275-1280) şi Ştefan Uros II Milutin (1282-1321). Ultimul, cel de la Dragijevo, avea în asociere monede din timpul lui Andronic al II-lea (1282-1328) şi Mihail al IX-lea Paleologul (1295-1320).

\footnotetext{
${ }^{16} 0$ 19 2010. 117-138.

${ }^{17} 0$ ) 2009. 195.196, 200. 201.

${ }^{18}$ Bobceva 1978, 160, 169, 173. 178. Гab. VIII/M. 130/1. Tab. XIII/M. 210/1-2. Tab. XV/M. 321/1. Tab. XVIl/b.

${ }^{19}$ Constantinescu 1972. 100.
}

Datorită faptului că piesele de la Dobrogled au bune analogii în cele de la Coconi şi Isaccea, le putem data şi pe ele în aceeaşi vreme.

Tezaurul de la Jiana Mare conţine piese asemănătoare stilistic. În ambele cazuri datările au fost realizate cu monede emise din ultimul sfert al secolului al XIV-lea până în primul sfert al celui de-al XV-lea. Tipul pandantivelor care decorează veriga este şi el specific secolelor XIV-XV. Acesta are bune analogii în piesele descoperite la DroberaTurmu Severin -termele romane ${ }^{20}$, Vărădia ${ }^{21}$, precum alţi cercei din aceleaşi tezaure de la .Jiana Mare ${ }^{22}$, Olteni ${ }^{23}$ şi Orşova ${ }^{24}$.

Cerceii de la Dragijevo, cuprind două variante. Asocierea lor în acelaşi tezaur şi datarea cu monede, demonstrează durata de utilizare a două motive decorative, nu doar pentru ele, ci şi pentru alte piese asemănătoare. Cel mai vechi model este reprezentat de cerceii cu pandantive laterale sferice ajurate. Cel de-al doilea, prin motivele decorative auxiliare (pandantive laterale sferice, din plăcuțe circulare decorate cu granule şi filigran) indică un model care a fost în uz foarte probabil de la sfârşitul secolului al XIII-lea şi pe parcursul celui de-al XIV-lea. Elementul care pledează pentru o încadrare în veacul al XIII-lea este veriga de bară simplă. Argumentul pentru datarea în secolul al XIV-lea ar fi pandantivele laterale ale piesei de la Sumen. Monedele din tezaurul de la Dragijevo lasă deschisă discuţia, piesele putând fi încadrate spre sfârş̧itul secolului al XIII-lea şi primul sfert al celui de al XIV-lea.

În cazul pieselor de la Skravena, datarea este destul de simplă, adică în prima jumătate a secolului al XIII-lea. Similitudinea acestei piese cu cea descoperită în teritoriul oraşului Drobeta-Turnu Severin, indică faptul că şi aceasta din urmă trebuie datală foarte probabil în aceeaşi vreme.

\footnotetext{
20 Dumitriu 2001, 122. Taf. 37/8.

21 [Florescu. Miclea 1979. 82, fig. 228

2 Dumitriu 2001. 127, Tal. 39/1-5.

2: Dumitriu 2001. 130. Tal. 42/3-4.

24. Teicu 2009. 98, 110 . PI. 46/1.
} 


\section{Concluzii}

Ca urmare a acestei analize, putem spune că se conturează patru tipuri de decor executat din foită de argint, aur, bronz sau bronz argintat.

În funcţie de modelele de cercei pe care apar, se disting mai multe tipuri şi sub-tipuri de cercei.

În ordine cronologică, prima grupă decorativă este formată de cerceii decoraţi cu paraboloide. Aceştia, din punct de vedere geografic cuprind două arii de difuzare.

Prima este spaļiul dalmat. Cronologia lor este circumscrisă secolelor IX-X (XI). Din punct de vedere tipologic, se disting două mari grupe. Prima dintre ele este formată de piesele descoperite în cimitirele de la Bribir, Brenkovac şi Biskupija. Acestea se caracterizcază prin montura decorată cu trei rânduri de paraboloide ( $\mathrm{PI} .1 / 1-4)$. În cadrul lor se disting trei variante: l: piesele de la Bribir (PI. 1/l-2), 2: piesele de la Brenkovac (PI. 1/3) şi 3: piesa de la Biskupija (PI. 1/4).

A doua grupă este reprezentată de o picsă descoperită la Biskupija (PI. 1/5).

Cea de-a doua regiune de difuzare este în spaţiul est balcanic. Piesele de aici sunt mai târzii şi aparţin secolului al XIV-lea. În acest ca\% piesele sunt din punct de vedere formal aproape identice, dar diferă materialul de execuție şi numărul pandantivelor. În funcţie de accst criteriu, putcm distinge cinci variante: 1) piesa de la Coconi (Pl. 1/6), 2) piesele de la Dohrogled (PI. 1/8-9), 3) cercelul de la IsacceaBurg (PI. 1/7), 4) o pereche de cercei de la Divdicadovo (PI. 1/10-11) şi o alta 5) cu două monturi sferice provenită din aceeaşi localitate (PI. 1/12-13). Faptul că sunt din materiale diferite (bronz, bronz argintat şi aur) sugerează cà provin din ateliere diferite. Limitarea răspândirii lor la nord-estul Balcanilor, sugerează că aici exista moda confecţionării şi utilizării lor şi putem vorbi doar de un produs cu utilizare regională.

$\Lambda$ doua grupă decorativă este formată din conuri. Şi aici se disting mai multe tipuri, grupe şi sub-grupe de cercei pe care apare decorul.

Cel mai simplu tip este format de cercelul descoperit la Enisala, decorat cu o singură montură. Din punct de vedere al repartiţiei geografice el se circumscrie spaţiului nord şi vest Pontic controlat de către triburile tiurkice.
Cronologia sa sugereaza o datare în cursul secolelor XII-XIII.

Al doilea tip cuprinde cercei decoraţi cu trei monturi (Braničevo, Kalna, Cernăuti, Prilep, Cuptoare, Păcuiul lui Soare, Jiana Mare). În funcţie de modul de execuţie al verigii, se disting două subtipuri, anume cele simple şi cele din sârmă torsionată. În cadrul fiecăreia se disting mai inulte grupe, în funcţie de caracteristicile de execuţie a verigilor şi monturilor.

Prima grupă cuprinde piesele găsite la Braničevo şi Kalna (verigi simple, decor identic pe toate cele trei pandantive, dimensiuni diferite ale monturilor). Similitudinea de confecţionare precum şi aria de răspândire sugerează proveniența dintr-un atelier comun de la Dunărea Mijlocie care a funcţionat cândva la sfârşitul secolului al XIIIlea și eventual începutul veacului următor.

A doua grupă cuprinde piesele care au pandantivele laterale decoraţi diferit de cel central (Cernăuti, Voineşti, Prilep. Cuproare, Păcuiul lui Soare şi Jiana Mare).

Prima sub-grupă este formată de picscle de la Cernăuti (verigã simplă).

Cea de-a doua se constituie din acele exemplare cu veriga din sârmă torsionată (Voinești, Voineşti, Prilep. Cuptoare, Păcuiul lui Soare). În functie de modelul decorului de pe pandantivul central şi a modului de cxecuţic al celor laterali, se disting următoarele variante: rate).

a. Prilep, Cuptoare (monturile laterale aju-

b. Voinești (monturile laterale decorate cu pseudo-granule). discuri)

c. Păcuiul lui Soare (monturile laterale din

Lơr li se mai adaugă o piesă, anuıne cea descoperită în tezaurul de la Jiana Mare. În acest caz, nu se cunoaşte cu exactitate dacă avea veriga simplă sau torsionatã. Analogiile de piese decorate asemănător sugerează că majoritatea exemplarelor decorate cu monturi în formă de elipsoid aveau veriga din sârmă pusă în două şi torsionată. În acest sens aş cita piesele de la Olteni, Jiana Mare şi Jidosija ${ }^{25}$.

\footnotetext{
${ }^{25}$ Numārul lor este mai mare, dar în multe cazuri verigile sunt rupte. Este vorba despre piesele de la Drobeta Tirm Severin-lermele romane, lärä́dia. Mult mai reduse numeric sunt acele exemplare care au veriga simplă.
} 
Cronologia lor indică utilizarea cerceilor începând cu ultimul sfert al secolului al XIIIlea până în primii 20 de ani ai veacului al XVlea.

A treia grupă decorativă cuprinde piesele decorate cu piramide din foiţă metalică. În acest caz se disting două grupe. Prima dintre ele se constituie din acele piese cu veriga simplà (Skravena, Drobeta-Turnu Severin. Stara Zagora şi Sumen). Dacă piesele din primele două localităţi sunt extrem de asemănătoare, cele de la Stara Zagora (PI 3/4) şi Sumen sugerează ateliere de productie diferite. Cronologia celor dintâi este destul de clară, anume în al doilea sfert al secolului al XIII-lea.

Pe baza cronologiei relative pot fi datate şi exemplarele de la Stara Zagora şi Şumen, adică foarte probabil la limita secolelor XIIIXIV.

Cea de-a doua grupă este formată din cerceii descoperiţi la Dragijevo. Aceştia, având în vedere caracteristicile decorative, se împart la rândul lor în două sub-grupe. Prima este formată din perechea de cercei cu pandantivele laterale ajurate. Cea de-a doua este reprezentată de ce de-al treilea cercel din tezaur. Datarea lor se face în special pe baza cronologiei absolute, la sfârşitul secolului al XIII-lea şi începutul celui de-al XIV-lea. Lor li se mai poate adăuga un exemplar parţial distrus şi care provine dintr-o localitate neprecizată din Bulgaria. Acesta are bune analogii cu veriga și pandantivul celui de-al treilea cercel de la Dragijevo şi cu pandantivul central al piesei de la Sumen.

A patra grupă decorativă este formată din picsa de la Nikopol. Aceasta se poate data in cursul secolului al XIV-lea pe baza caracteristicilor de execuţie şi decorative.

În urma acestei analize, putem spune că suntem în faţa unor modele decorative în relief aplicate pe pandantivul unor cercei, fără să îi putem atribui etnic. Faptul că apar sub formă de paraboloid, piramidă, con sau tetraedru nu reprezintă decât variante şi preferinţe locale ale populaţiei sau ale meşterilor care confecționau aceste piese. Un alt argument ar fi acela că apar pe destul de multe tipuri de cercei, nu pe unul anume.

De asemenea, considerăm că încercarea de atribuire a pandantivelor biconice influenţelor orfevrierilor cumani este eronată. Acest tip de pandantiv se regăseşte în orfevrăria sud-estului european cu mult înaintea venirii cumanilor, în zona balcanică. Nici măcar stilul decorului nu se poate lega de o populaţie anume. Mai degrabă putem spune că el a fost la modă în anumite spaţii şi perioade de timp. Utilizarea termenului cercei de tip cuman se datorează mai degrabă dorinţei unor arheologi de a distinge un anumit model de cercei de alţii (cei cu pandantiv biconic uneori). Tendinţa este cauzată şi de faptul că în acest mod vor să demonstreze sau alteori să constate influenţa orfevrierilor cumani, diferenţiindu-i de cei care au activat în cadrul celorlalte populaţii din sud-estul Europei. Tot în acelaşi scop a fost utilizat şi argumentul decorului suplimentar aplicat pandantivelor unor cercei. Din această dorinţă s-a ajuns la confuzii între tipurile de cercei, ca de exemplu cercei de tip Tokaj cu cei de tip cuman.

\section{BIBLIOGRAFIE}

Agrè 1990 - D. Agrè, Mogila No. I ot nekropola Kraj selo Skravena, Botevgradsko, ArcheologijaSof, 32, 19903, p. 17-31.

Bobčeva 1978 - L. Bobčeva, Nekropole des 13. -14. Jhs. In Kaliakra, IzvVama, XIV (XXIV), 1978, p. 152180

Constantinescu 1972 - N. Constantinescu, Coconi. Un sat din Cîmpia Romänă in epoca lui Mircea cel Bătrân. Studin arheologic și istoric, Bucureşti, 1972.

Ćorović-Ljubinković 1954 - M. Ćorović-Ljubinković, Naušnice T. Z. Tokajskog tipa, RadMuzejaVM, 3, 1954, p. $81-93$

Diaconu, Baraschi 1977 - P. Diaconu, S. Baraschi, Păcuiul lui Soare. Așezarea medievală, vol. II, București, 1977. 
Dumitriu 2001 - L. Dumitriu, Der Mittelalterliche Schmuck des Unteren Donaugebietes im II. -IS. Juhrhundert, Bucureşti, $200 \mathrm{I}$.

Filow 1919 - B. D Filow, L'ancien art Bulgare, Berna, 1919.

Florescu, Miclea 1979 - R. Florescu, I. Miclea, Tezaure transilvane la Kunsthistorisches Museum din Viena, București, 1979.

Gcorgieva 1961 - S. Georgieva, Bălgarskite srednovekovnih nakiti, ArcheologijaSof, III, 1961, 1, p. 4-10.

Jelovina 1976 - D. Jelovina. Starohrvatske nekropole. Na području izmedu rijeka zrmanje I cetine, Split, 1976.

Kuzev 1961 - A. Kuzev,Grošsve na Stefan Dušan s kontramarku, ArcheologijaSof, III, 1961, 2, p. 14-17.

Maneva 1992 - E. Maneva, Srednovekoven nakit od Makedonija, Skopje, 1992.

Mollov 1926-1927 - I. Mollov, Arheologičeski nahodki vă Sumensko, BIBulg, IV, 1926-1927, p. 301-303.

Neševa 1985 - V. Neševa Srednovekovnih nakit ot Varnenskija Muzej, IzvVarna, 21 (36), 1985, p. 114-120 şi Tabl. 1-5.

Oța 2008 -. S. Oța, Orizonturi funerare din Banatul istoric (secolele X-XIV), Sibiu, 2008.

Oța 2009a - S. Oța, Podoabe de influentă bizantină şi orientală de pe teritoriul Banatului istoric (secolele $X I I I-X I V)$. În: V. Sîrbu, C. Luca (editori), Miscellanea Historica et Archaeloogica in Honorem Professoris Ionel Cándea, Brăila, 2009, p. 75-97.

Oța 2009b - S. Oța, Câteva date privind decorul unor cercei de traditie bizantină descoperiti în Peninsula Balcanică, Istros, XV, 2009, p. 179-211.

Ota 2010 - S. Oţa, Cercei decorati cu pandantiv sferic ajurat in sud-estul Europei (secolele XIII-XIV), Apulum, XLVII, 2010 , p. 117-138.

Pletneva 1981 - S. A. Pletneva, Kö́evniki vostočnoevropejskih stepej v X-XIII vv. Pečenegi, torki, polovc'i, în Stepi Evrazii v epohu ssrednevekova, Arheologiia SSSR. 21, 1981, p. 213-222.

Popović, Ivanisević 1988 - M. Popović, V. Ivanisević, Braničevo, cité médiévale, Starinar, 39, 1987 (apare 1988), p. 125-179.

Spinci 1994 - V. Spinei, Moldova in secolele XI-XIV, Chişinău, 1994.

Tcodor 2003a - D. Gh. Teodor, Tezaurul feudal timpuriu de obiecte de podoabă descoperit la Voinești-Iaşi, p. 147--162. În: Spatiul carpato-dunăreano-pontic în mileniul marilor migratii, Buzău, 2003.

'Tcodor 2003b - D. Gh. Teodor, Obiecte de podoabă din tezaurul feudal descoperit la Oleleni (raionul Huşi, reg. Iaşi). p. 163-175. În: Spațiul carpato-dunăreano-pontic in mileniul marilor migratii, Buzău, 2003.

Teicu 1993 - D. Teicu, Necropole medievale (sec. X-XIV) din sudul Banatului, Banatica, 12, 1993, I, p. 229 272.

Teicu 1998 - D. Teicu, Banatul montan in evul mediu, Timişoara, 1998.

Teicu 2009 - D. Teicu, Arta minoră medievală din Banat, Timişoara, 2009.

***Istoria na Bălgaria. Tom treti. Vtora Bălgarska dăržava, Sofia, 1982

***Nakit na tlu sjeverne Dalmacije od prapovijesti do danas, Izložba, Zadar, 1981

\section{LISTA ILUSTRAȚIEI:}

PI. 1 - 1-2. Bribir-Vratnice; 3. Brenkovac-Podgrađe; 4. Biskupija-Crkvine (după Jelovina 1796); 6. Coconi (după Constantinescu 1972); 7. Iasceea (după Dumitriu 2001); 8-9. Dobrogled (după Kuzev 1961); $10-13$. Divdiadovo (după Mollov 1926-1927); 14. Enisala (după Dumitriu 2001).

PI. 2 - 1-2. Braničevo-Rudine (după Popović, Ivanišević 1988); 3-4. Kalna; 5. Cernăuţi (după ĆorovićLjubinković 1954); 6. Voineşti; 7-8. Cuptoare-Sfogea (după Teicu 1998); 9. Prilep (după Maneva 1992); 10. Păcuiul lui Soare; 11. Jiana Mare (după Dumitriu 2001).

Pl. 3 - 1. Drobeta-Turnu Severin (după Dumitriu 2001); 2-3. Skravena (după Agrè 1990); 4. Stara Zagora; 5. Şumen (după Istoraia na Bălgaria, III, 1982); 6-8. Dragijevo (după Filow 1919); 9. Localitate nespecificată din Bulgaria (după Georgieva 1961); 10. Nikopol (după ArcheologijaSof 1983).

PI. 4 -. Harta cu localizările punctelor din catalog

\section{LIST OF ILLUSTRATION}

Sketch 1 - 1-2. Bribir-Vratnice; 3. Brenkovac-Podgrađe; 4. Biskupija-Crkvine (according to Jelovina 1976); 6. Coconi (according to Constantinescu 1972); 7. lasceea (according to Dumitriu 2001); 8-9. Dobrogled (according to Kuzev 1961); 10-13. Divdiadovo (according to Mollov 1926-1927); 14. Enisala (according to Dumitriu $2001)$ 
Sketch 2 - 1-2. Braničevo-Rudine (according to Popović, Ivanišević 1988); 3-4. Kalna; 5. Cernăuţi (according to Ćorović-Ljubinković 1954); 6. Voineşti; 7-8. Cuptoare-Sfogea (according to Teicu 1998); 9. Prilep (according to Maneva 1992); 10. Păcuiul lui Soare; 11. Jiana Mare (according to Dumitriu 2001).

Sketch 3 - 1. Drobeta-Turnu Severin (according to Dumitriu 2001); 2-3. Skravena (according to Agrè 1990); 4. Stara Zagora; 5. Şumen (according to Istoria na Bălgaria, III, 1982); 6-8. Dragijevo (according to Filow 1919); 9. Unspecified locality in Bulgaria (according to Georgieva 1961); 10. Nikopol (according to ArcheologijaSof 1983).

Sketch 4 - Map containing the location of the points in the catalog

SILVIU OTA

Muzeul Naţional de Istorie a României,

Calea Victoriei, nr. 12, sector 3, 030026

Bucureşti

silviuota@yahoo.com 

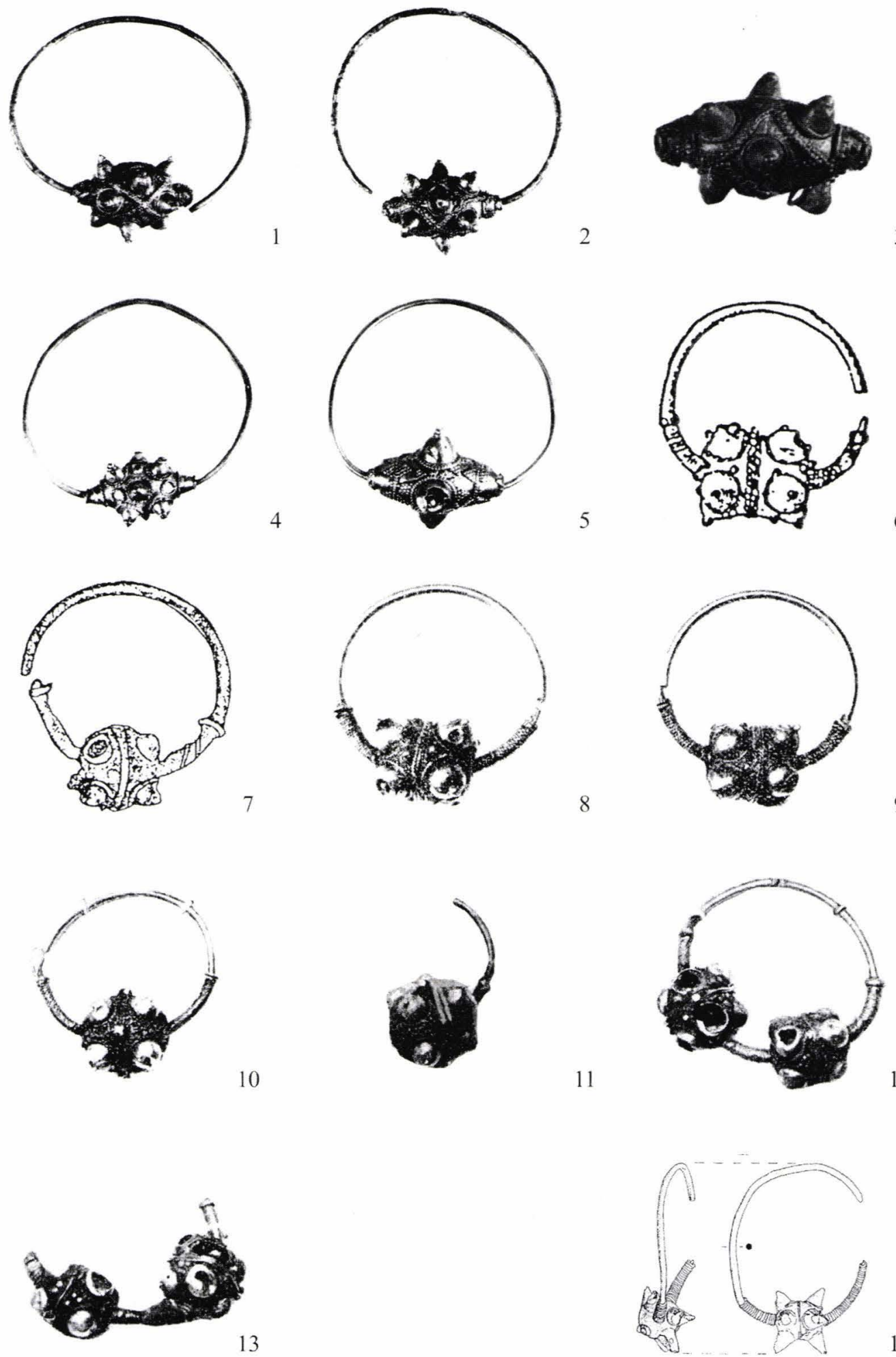

PI. 1 - 1-2. Bribir-Vratnice; 3. Brenkovac-Podgrade; 4-5. Biskupija-Crkvine (după Jelovina 1976); 6. Coconi (după Constantinescu 1972); 7. Isaccea (după Dumitriu 2001);

8-9. Dobrogled (după Kuzev 1961); 10-13. Divdiadovo (după Mollov 1926-1927);

14. Enisala (după Dumitriu 2001). Ilustraţii fără scară. 

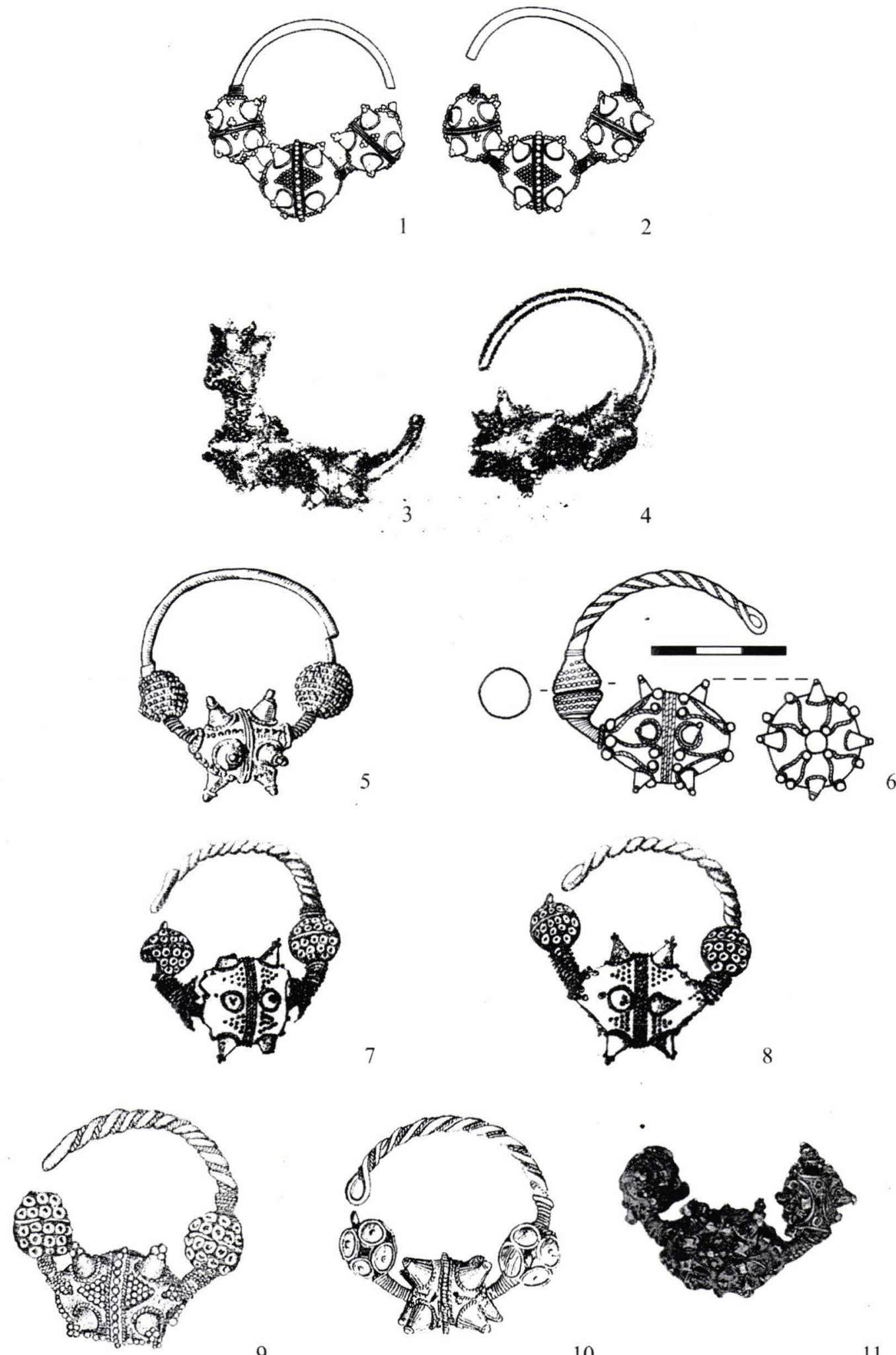

9

10

11

Pl. 2 - 1-2. Braničevo-Rudine (după Popovic, Ivanišević 1988; 3-4. Kalna; 5. Cernăuţi (după Ćorović-Ljubinković 1954); 6. Voineşti; 7-8. Cuptoare-Sfogea (după Teicu 1998);

9. Prilep (după Maneva 1992); 10. Păcuiul lui Soare; 11. Jiana Mare (după Dumitriu 2001). Iustrații fără scară. 

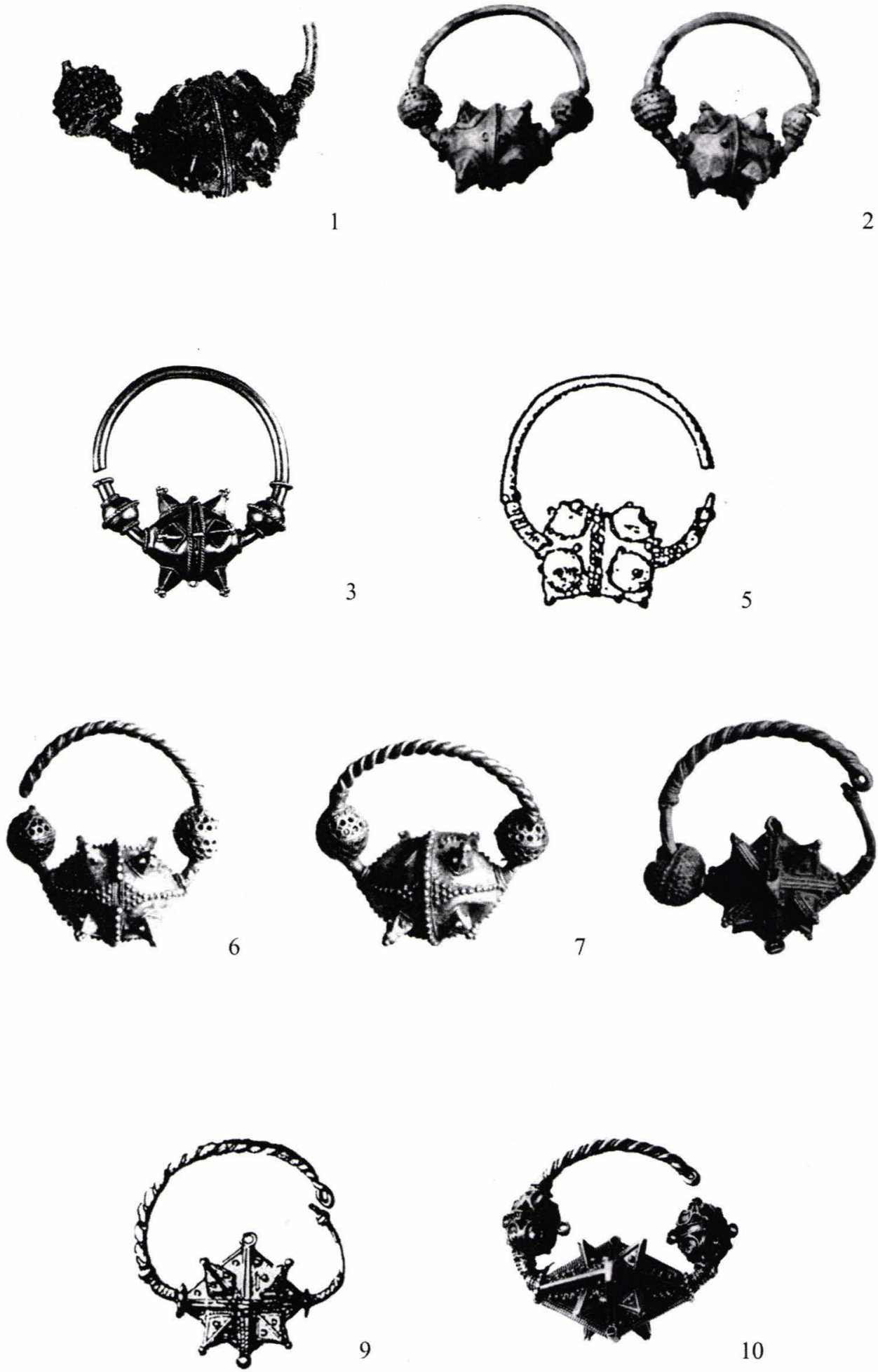

10

Pl. 3 - 1. Drobeta-Turnu Severin (după Dumitriu 2001); 2-3. Skravena (după Agrè 1990);

4. Stara Zagora; 5. Şumen (după Istoria na Bălgaria, III, 1982); 6-8. Dragijevo (după Filow 1919); 9. Localitate nespecificată din Bulgaria (după Georgieva 1961); 10. Nikopol (după ArheologijaSof 1983). Ilustraţii fără scară. 


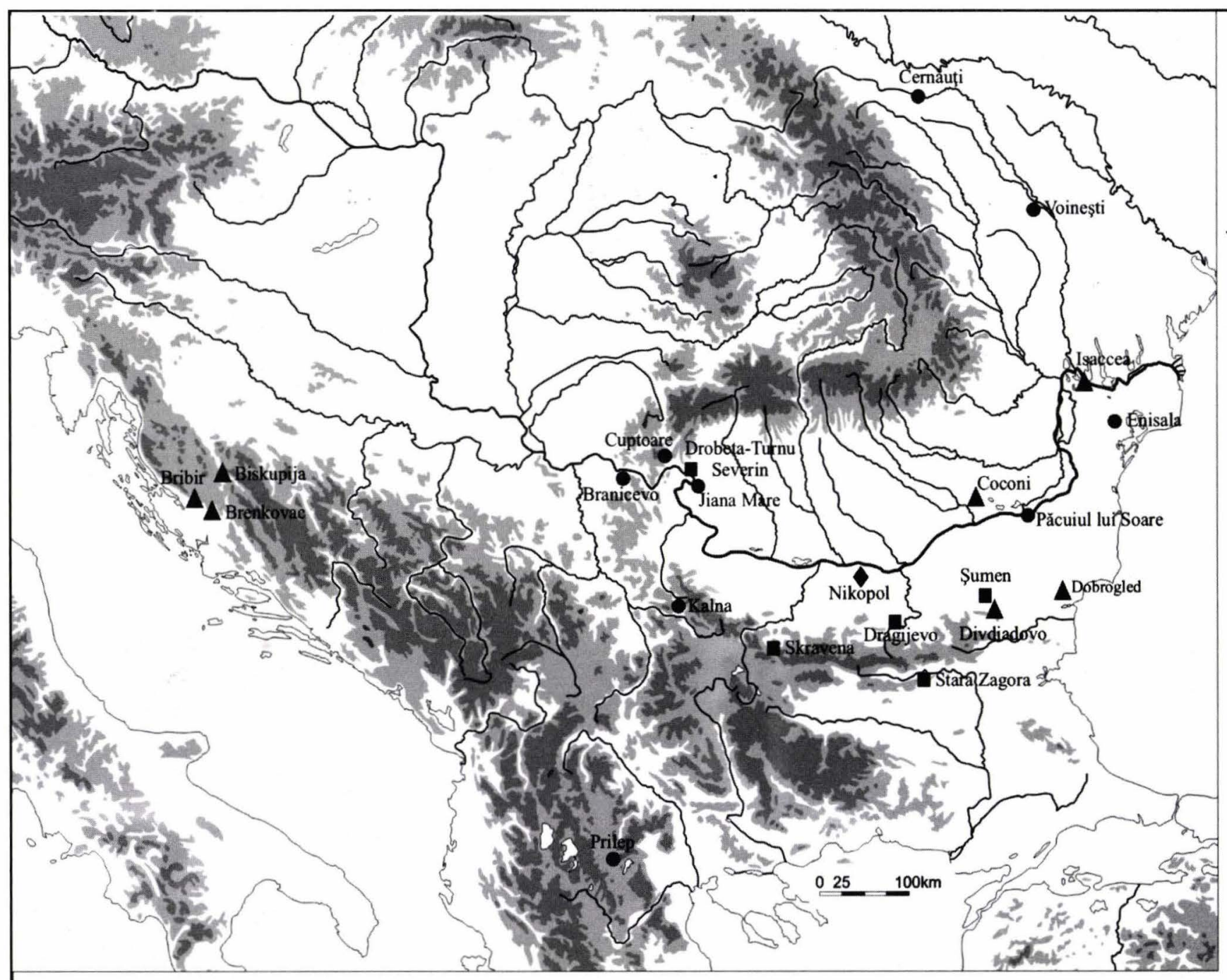

Legenda

$\Delta$ Cercei decoraţi cu proeminențe în formă de paraboloid

- Cercei decoraţi cu proeminenţe în formă de conuri

- Cercei decoraţi cu proeminenţe în formă de tetraedru

- Cercei decorați cu proeminențe în formă de piramidă

Pl. 4 